\title{
Resistance to Fas-mediated apoptosis in human lung fibroblast
}

\author{
T. Tanaka, M. Yoshimi, T. Maeyama, N. Hagimoto, K. Kuwano, N. Hara
}

\begin{abstract}
Resistance to Fas-mediated apoptosis in human lung fibroblast. T. Tanaka, M. Yoshimi, T. Maeyama, N. Hagimoto, K. Kuwano, N. Hara. (C) ERS Journals Ltd 2002. ABSTRACT: The current authors have demonstrated previously that epithelial cell apoptosis, induced by the Fas-Fas ligand pathway, might be involved in fibrosing lung diseases. Whereas lung epithelial cells are sensitive to the Fas-mediated apoptosis, lung fibroblasts may be resistant to Fas-mediated apoptosis and replace damaged epithelial cells.

The WI-38 lung fibroblast cell line and primary lung fibroblasts were used to examine the resistant to Fas-mediated apoptosis and the association of anti-apoptotic proteins with this resistance.

The administration of agonistic anti-Fas antibody $(\mathrm{CH}-11)$ or cycloheximide alone did not induce apoptosis, whereas the co-administration of $\mathrm{CH}-11$ with cycloheximide induced apoptosis in WI-38 cells, in which caspase-8 and -3, but not -9, were activated, and $X$ chromosome-linked inhibitor of apoptosis (ILP) and FLICE-like inhibitor protein $\left(\right.$ FLIP $\left._{L}\right)$, but not bcl- $x_{L}$ and bcl-2, were remarkably down regulated. Primary lung fibroblasts were also resistant to Fas-mediated apoptosis, and ILP and FLIP appeared to be involved in this resistance. Furthermore, the results of immunohistochemistry demonstrated that fibroblasts expressed ILP and FLIP $_{L}$ proteins in lung tissues from patients with idiopathic pulmonary fibrosis.

These results suggest that anti-apoptotic proteins such as $\mathbf{X}$ chromosome-linked inhibitor of apoptosis and FLICE-like inhibitor protein may play an important role in preventing Fas-mediated apoptosis in lung fibroblasts, and participate in the development of pulmonary fibrosis.
\end{abstract}

Eur Respir J 2002; 20: 359-368.
Research Institute for Diseases of the Chest, Graduate School of Medical Sciences, Kyushu University, Higashiku, Fukuoka, Japan

Correspondence: K. Kuwano

Research Institute for Diseases of the Chest

Graduate School of Medical Sciences Kyushu University

3-1-1 Maidashi

Higashiku

Fukuoka 812

Japan

Fax: 81926425389

E-mail: kkuwano@kokyu.med.

kyushu-u.ac.jp

Keywords: Apoptosis

Fas

fibroblast

pulmonary fibrosis

Received: June 142001

Accepted after revision: March 62002
Fas antigen (Fas), a type I membrane receptor protein and a member of the tumour necrosis factor (TNF) receptor family [1], induces apoptosis after engagement by Fas ligand (FasL) [2]. FasL is a type II membrane protein that belongs to the TNF family, and is expressed predominantly in activated T-cells [2]. Fas is expressed in various cells and tissues including the thymus, liver, skin, heart and lungs [3-5]. It is suggested that the loss of parenchymal cells through the Fas pathway might play an important role in tissue injury or organ dysfunction $[3,6]$.

Damage to, and the loss of, epithelial cells, which subsequently leads to pulmonary fibrosis, are commonly seen in acute lung injury and chronic fibrosing alveolitis. The present authors previously demonstrated that the Fas-FasL pathway might be associated with the pathophysiology of idiopathic pulmonary fibrosis (IPF) [7]. The important role of the Fas-FasL pathway in apoptosis of alveolar epithelial cells was also reported in vitro [5]. Using in situ deoxyribonucleic acid (DNA) nick end-labelling and electron microscopic examinations in lung tissues from patients with IPF [8] and animal models of pulmonary fibrosis [9], it was found that apoptotic cells were mainly epithelial cells, but not fibroblasts. Furthermore, inhalation of agonistic anti-Fas antibody induced apoptosis in lung epithelial cells, but not in fibroblasts, which subsequently led to pulmonary fibrosis in mice [10]. These results imply that the resistance of fibroblasts to Fas-mediated apoptosis may be associated with the pathophysiology of pulmonary fibrosis.

The bcl-2 family of proteins modulate cell survival $[11,12]$. The bcl-2 protein is an intracellular membrane-associated protein whose overexpression prevents cell death $[11,13]$. Bcl-x gene encodes two proteins; bcl- $x_{L}$ protects cells from survival factor deprivation-induced apoptosis, while the overexpression of bcl- $x_{S}$ predisposes cells to apoptosis [12]. Overexpression of bcl-2 partially prevents Fas-mediated apoptosis [14].

One of the intracellular signalling events required for apoptosis is the activation of caspases. A caspase cascade, beginning with the activation of "initiator" caspases such as caspase-8, leads to the activation of "effector" caspases such as caspase-3, -6, or -7. These effector caspases subsequently cleave protein substrates, including polyadenosine diphosphate ribose polymerase, lamins and DNA-dependent protein kinase, resulting in the morphological features of apoptosis [15].

Recently, the inhibitor of apoptosis (IAP) family of genes has been identified. The expression of these inhibitors are induced by nuclear factor $-\kappa B(N F-\kappa B)$ activation. The $\mathrm{X}$ chromosome-linked IAP (ILP) suppresses the apoptosis signalling by the direct 
inhibition of activated caspase-3 [16]. A procaspase $3 / \mathrm{p} 21$ complex formation and the direct inhibition of activated caspase- 3 by ILP induce caspase- 3 inactivation [17].

Following FasL ligation to Fas, Fas binds to Fasassociating protein with death domain (FADD) [18]. FADD binds to caspase- 8 through its death effector domain and produces a death-inducing signalling complex, leading to the activation of caspase-8. Activated caspase- 8 induces the activation of a caspases cascade, that directly leads to apoptotic cell death. Activated caspace-8 also cleaves bcl-2 interacting domain (BID) to generate truncated BID that translocates to the mitochondria and induces the release of cytochrome c. Released cytochrome c activates caspace- 9 that results in the activation of the caspase cascade. A FLICE-like inhibitor protein $\left(\right.$ FLIP $\left._{\mathrm{L} / \mathrm{S}}\right)$ was first described as a viral product that inhibited Fas- and TNF-mediated apoptosis [19]. Like viral FLIP $_{\mathrm{L} / \mathrm{S}}$, cellular FLIP $_{\mathrm{L} / \mathrm{S}}$ competitively inhibits the binding of caspase- 8 to the Fas receptor complex and blocks the Fas signalling pathway [20].

The purpose of this study was to examine the expression of anti-apoptosic proteins, and to investigate the mechanism of resistance to Fas-mediated apoptosis in lung fibroblasts. The study also examined how WI-38 cells differ from primary human lung fibroblasts. As previously reported, the present authors found that WI-38 cells are resistant to Fas ligation unless cycloheximide is added [21]. Furthermore, ILP and FLIP $_{\mathrm{L}}$ protein expression in lung tissues from patients with IPF was investigated.

\section{Methods}

\section{Cell culture}

A human lung fibroblast cell line (WI-38; Riken cell Bank, Tsukuba, Japan) WI-38 was derived from normal embryonic lung tissue. These cells were grown in $25 \mathrm{~cm}^{2}$ tissue culture flasks (Falcon, Franklin Lakes, NJ, USA) in growth medium, which consisted of Dulbecco's Modified Eagle Medium (Gibco, Grand Island, NY, USA) with 10\% foetal bovine serum and $1 \%$ penicillin streptomycin. These cultures were incubated at $37^{\circ} \mathrm{C}$ in a humidified, $95 \%$ air $/ 5 \%$ carbon dioxide $\left(\mathrm{CO}_{2}\right)$ atmosphere. When the cells were subconfluent, they were harvested by trypsinisation and plated in another flask in the same medium.

\section{Expression of Fas antigen assessed by flow cytometry}

For analysis of Fas surface expression on WI-38 cells, unstimulated cells and cells treated with either $4 \mathrm{ng} \cdot \mathrm{mL}^{-1}$ TNF- $\alpha$ (Dainippon Pharmaceutical Co. Ltd, Tokyo, Japan) for $24 \mathrm{~h}, 40 \mathrm{ng} \cdot \mathrm{mL}^{-1}$ interferon (IFN) $-\gamma$ (Shionogi Co. Ltd, Tokyo, Japan) for $6 \mathrm{~h}$, or $4 \mathrm{ng} \cdot \mathrm{mL}^{-1} \mathrm{TNF}-\alpha$ for $24 \mathrm{~h}$ with $40 \mathrm{ng} \cdot \mathrm{mL}^{-1}$ IFN- $\gamma$ pretreatment for $6 \mathrm{~h}$ were removed from the plate with $5 \mathrm{mM}$ ethylenediamine tetraacetic acid (EDTA), pelleted, and resuspended in a staining solution containing phosphate-buffered saline (PBS) with $1 \%$ foetal calf serum. Cells were labelled with $1 \mu \mathrm{g} \cdot \mathrm{mL}^{-1}$ fluorescein isothiocyanate (FITC)-conjugated mouse anti-human Fas antibody (clone U132; MBL, Nagoya, Japan) or control FITC-conjugated mouse immunoglobulin (Ig)-G (MBL) for $45 \mathrm{~min}$ at $4^{\circ} \mathrm{C}$. Ten thousand viable cells were analysed on a Coulter EPICS XL flow cytometer (Coulter Corp., Hialeah, FL, USA).

\section{MTT (3-[4,5-dimethylthiazol-2-yl]-2,5-diphenyl tetrazolium bromide) assay}

The MTT (3-[4,5-dimethylthiazol-2-yl]-2,5-diphenyl tetrazolium bromide) (Sigma Chemical Co. St Louis, MO, USA) assay was carried out as described previously [22]. Briefly, WI-38 cells were incubated for $24 \mathrm{~h}$ in 96-well tissue culture plates and treated with $0.01-1000 \mathrm{ng} \cdot \mathrm{mL}^{-1} \mathrm{TNF}-\alpha$ or anti-human Fas monoclonal antibody (CH-11; MBL) in a humidified atmosphere of $5 \% \mathrm{CO}_{2}$ incubator at $37^{\circ} \mathrm{C}$. After $24 \mathrm{~h}$, $0.1 \mathrm{mg} \cdot 50 \mu \mathrm{L}^{-1}$ MTT was added and the plate was incubated for $4 \mathrm{~h}$ at $37^{\circ} \mathrm{C}$ and subsequently centrifuged at $800 \times g$ for $10 \mathrm{~min}$, and the media was removed.

Following centrifugation for $10 \mathrm{~min}$ at $400 \times g$, the supernatants were removed. MTT formazon crystals were then solubilised by adding $200 \mathrm{~mL}$ dimethyl sulfoxide and absorbance was measured using an automated microplate reader at a wavelength of $540 \mathrm{~nm}$ (Easy Reader EAR 340; SLT Lab instruments, Salzburg, Austria). The value of the sample with medium alone was regarded as $100 \%$ survival.

\section{Detection of apoptosis by flow cytometry}

Apo2.7 antibody (Coulter Corp.) reacts with a 38$\mathrm{kDa}$ mitochondrial membrane protein (7A6 antigen) which appears to be exposed on cells undergoing apoptosis. It has been suggested that the Apo2.7 protein is involved in the molecular cascade of apoptosis and its expression represents an early event in apoptosis rather than a final product in dead cells [23]. In addition apoptosis was assessed using propidium iodide (PI) (Calbiochem-Novabiochem Corp., La Jolla, CA, USA) to assess DNA fragmentation.

For analysis of apoptosis in WI-38 cells, unstimulated cells and cells treated with $100 \mathrm{ng} \cdot \mathrm{mL}^{-1} \mathrm{CH}-11$ for $24 \mathrm{~h}, 40 \mathrm{ng} \cdot \mathrm{mL}^{-1}$ IFN- $\gamma$ for $6 \mathrm{~h}$, or $4 \mathrm{ng} \cdot \mathrm{mL}^{-1}$ TNF- $\alpha$ for $24 \mathrm{~h}$ with $40 \mathrm{ng} \cdot \mathrm{mL}^{-1}$ IFN- $\gamma$ pretreatment for $6 \mathrm{~h}$ were removed from the plate with $5 \mathrm{mM}$ EDTA, pelleted and washed by PBS. Detached and floating cells were also recovered and included with those that were adherent when testing for apoptosis and for protein expression. To study whether antiapoptotic proteins are associated with the resistance to Fas-mediated apoptosis in WI-38 cells, the effects of cycloheximide (Wako Pure Chemistry Industries, Tokyo, Japan) on the induction of apoptosis and the expression of anti-apoptotic proteins was investigated. Cells were incubated in growth medium with $100 \mu \mathrm{g} \cdot \mathrm{mL}^{-1}$ cycloheximide alone or with cycloheximide and $100 \mathrm{ng} \cdot \mathrm{mL}^{-1} \mathrm{CH}-11$ for $24 \mathrm{~h}$. Following two washes by PBS, they were permeabilised in $100 \mu \mathrm{g} \cdot \mathrm{mL}^{-1}$ digitonin solution and incubated at 
$4{ }^{\circ} \mathrm{C}$ for $20 \mathrm{~min}$. Cells were washed and stained with $2 \mu \mathrm{g} \cdot \mathrm{mL}^{-1}$ of Apo2.7 monoclonal antibody for $15 \mathrm{~min}$. Cells were washed with $1.0 \mathrm{~mL}$ of PBS with $2.5 \%$ foetal calf serum and stored in the dark on ice. Ten thousand events were collected and analysed by flow cytometer. In experiments using PI the cells were washed twice in PBS, then resuspended in $2 \mathrm{~mL} \mathrm{70 \%}$ ethanol and incubated at $4{ }^{\circ} \mathrm{C}$ for $1 \mathrm{~h}$. Cells were washed with $\mathrm{PBS}, 0.5 \mathrm{~mL}$ of $1 \mathrm{mg} \cdot \mathrm{mL}^{-1}$ ribonuclease A (Sigma Chemical Co.), and $1 \mathrm{~mL}$ of $100 \mu \mathrm{g} \cdot \mathrm{mL}^{-1}$ were added and the cells were incubated at room temperature for $15 \mathrm{~min}$. Following two washes with PBS, the cells were analysed by flow cytometry.

\section{Electron microscopy}

Cells treated with $500 \mathrm{ng} \cdot \mathrm{mL}^{-1} \mathrm{CH}-11$ for $48 \mathrm{~h}$ were harvested following centrifugation, and fixed with $2.5 \%$ glutaraldehyde in $0.1 \mathrm{M}$ phosphate buffer, pH 7.4 for $18 \mathrm{~h}$. The cells were postfixed for $1.5 \mathrm{~h}$ in $1 \%$ osmium tetroxide $\left(\mathrm{OsO}_{4}\right)$ dissolved in $0.1 \mathrm{M}$ phosphate buffer ( $\mathrm{pH} 7.4$ ), and dehydrated through a series of graded ethanol solutions and embedded in Epon. Ultrathin sections were cut, stained with uranyl acetate and lead nitrate, and examined under a JEM1200 EX transmission electron microscope (JEOL Co., Tokyo, Japan).

\section{Western blotting}

WI-38 cells were incubated in growth medium with $100 \mathrm{ng} \cdot \mathrm{mL}^{-1} \mathrm{CH}-11,100 \mu \mathrm{g} \cdot \mathrm{mL}^{-1}$ cycloheximide, or $\mathrm{CH}-11$ with cycloheximide for $24 \mathrm{~h}$. Following two washes by PBS, the cells were harvested by trypsinisation. Cells were lysed by a hypotonic buffer containing $25 \mathrm{mM}$ Hepes, pH 7.5, $5 \mathrm{mM}$ $\mathrm{MgCl}_{2}, 1 \mathrm{mM}$ ethyleneglycol-bis-( $\beta$-aminoethylether)$\mathrm{N}, \mathrm{N}, \mathrm{N}^{\prime}, \mathrm{N}^{\prime}$-tetraacetic acid, $1 \mathrm{mM}$ phenylmethylsulfonyl fluoride (PMSF), $1 \mu \mathrm{g} \cdot \mathrm{mL}^{-1}$ leupeptin and $1 \mu \mathrm{g} \cdot \mathrm{mL}^{-1}$ aprotinin and centrifuged at $15000 \times \mathrm{g}$ for $10 \mathrm{~min}$. The total cell lysate of $1 \times 10^{6}$ cells was separated by $12 \%$ sodium dodecylsulfate-polyacrylamide gel electrophoresis, blotted onto a nitrocellulose membrane and blocked with $5 \%$ nonfat dry milk in trietyhanolamine-buffered saline (TBS) (10 mM TrisHCI pH7.5, $50 \mathrm{~m} \mathrm{M} \mathrm{NaCl}) /$ Tween $(0.1 \%$ Tween 20 in TBS).

Following washes with TBS/Tween, the blots were incubated for $16 \mathrm{~h}$ with hamster monoclonal antihuman bcl-2 antibody (83-8B; 1:200; MBL), rabbit polyclonal anti-human bcl-x $x_{\mathrm{S} / \mathrm{L}}$ antibody (S-18; 1:200; Santa Cruz Biotechnology, Santa Cruz, CA, USA), mouse monoclonal anti-human IAP-like protein antibody (2F1; 1:500; Transduction Laboratories, Lexington, KY, USA), rabbit polyclonal anti-human FLIP antibody (C-19; 1:500; Santa Cruz Biotechnology), goat polyclonal anti-human caspase-3 antibody (K-19; 1:200; Santa Cruz Biotechnology), rabbit polyclonal anti-human caspase-8 antibody (R\&D Systems, Inc., MN, USA), or rabbit polyclonal anti-human caspase9 antibody (R\&D Systems, Inc.) at $4^{\circ} \mathrm{C}$. Blots were washed again with TBS/Tween, incubated with horseradish peroxidase (HRP)-coupled isotype-specific secondary antibodies (1:500) for $1 \mathrm{~h}$ at room temperature, washed again, and developed with a ECL Western blotting detection reagent (Amersham, Buckinghamshire, UK). HRP-coupled anti-rabbit, anti-mouse, and anti-goat immunoglobulin were purchased from Santa Cruz Biotechnology. HRP-coupled protein G was purcahsed from Sigma-Aldrich (Tokyo, Japan) and FITC-labelled rat anti-hamster immunoglobulin was purchased from PharMingen Corp. (San Diego, CA, USA).

\section{Resistance to Fas-mediated apoptosis in primary human lung fibroblast}

To verify how WI-38 cells differ from primary lung fibroblasts, this study investigated whether primary human lung fibroblasts were resistant to Fas-mediated apoptosis and the expression of anti-apoptotic proteins. Cryopreserved primary human lung fibroblasts (Clonetics Corp., San Diego, CA, USA) and were used between passages two and five in this study, because the cell growth and the sensitivity to Fas ligation were constant during these passages (data not shown). These cells were grown in $25 \mathrm{~cm}^{2}$ tissue culture flasks (Falson) in fibroblast growth medium (FGM-2, Clonetics Corp.) supplemented with fibroblast growth factor-B $\left(1 \mathrm{ng} \cdot \mathrm{mL}^{-1}\right)$, insulin $\left(5 \mu \mathrm{g} \cdot \mathrm{mL}^{-1}\right)$, penicillin-streptomycin $\left(10 \mathrm{mg} \cdot \mathrm{mL}^{-1}\right)$, and $5 \%$ bovine serum albumin. Cell preparation methods for flow cytometry and western blotting were the same as those for WI-38, except that Annexin-V FITC (Roche Diagnostics, IN, USA) was used instead of Apo2.7 to detect apoptotic cells.

\section{Immunohistochemistry in human lung tissue}

Immunohistochemistry for ILP and FLIP $_{L}$ were performed on formalin-fixed, paraffin-embedded lung tissues, which consisted of specimens obtained by open lung biopsy from five patients with IPF and specimens obtained by lobectomy from five patients with solitary pulmonary nodules. Ages of IPF and controls ranged from 52-72 yrs (mean $60 \mathrm{yrs}$ ) and from 43-72 yrs (mean 56 yrs), respectively. All patients with IPF and controls were male and smokers. Following deparaffinisation, immunohistochemistry was performed using a modified streptavidinbiotinylated peroxidase technique using a Histofine SAB-PO kit (Nichirei Corporation, Tokyo, Japan). The sections were incubated with mouse monoclonal anti-human ILP antibody $(2 \mathrm{~F} 1 ; 1: 250)$ or rabbit polyclonal anti-human FLIP $_{\mathrm{L}}$ antibody (C-19; 1:250) at $4{ }^{\circ} \mathrm{C}$ overnight. The sections were rinsed with $\mathrm{PBS}$ and incubated with biotinylated anti-goat $\mathrm{IgG}$ for $30 \mathrm{~min}$. For control incubations, specific antibodies were replaced by nonimmune goat serum.

\section{Statistical analysis}

The results of the assay were analysed by one way analysis of variance with Bonferroni/Dunn's post hoc procedure. 

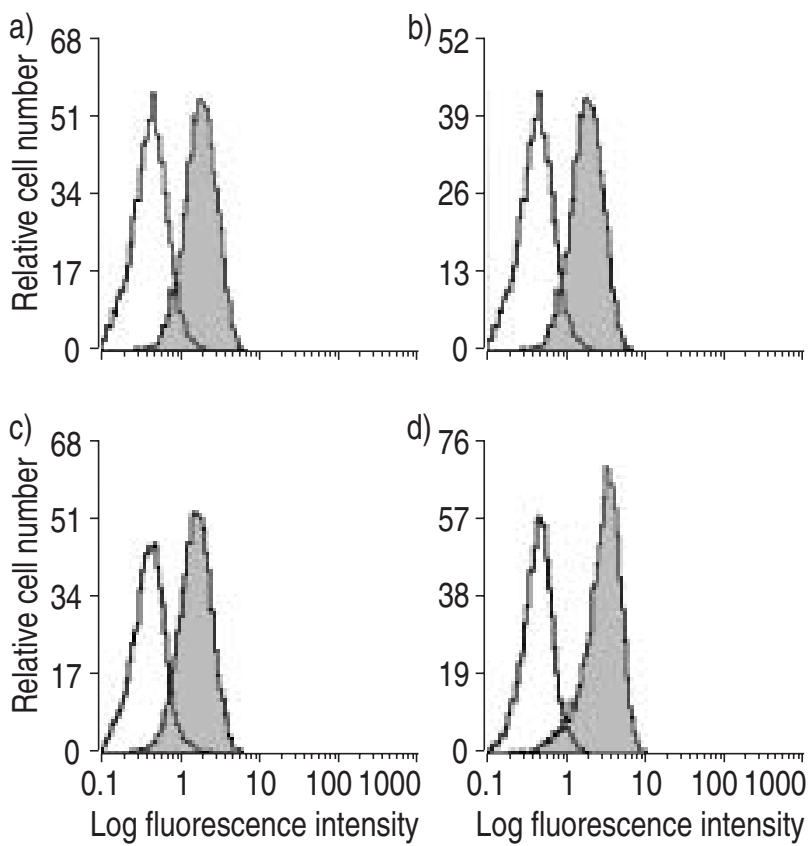

Fig. 1.-Fas expression on the surface of WI-38 cells, as determined by flow cytometry. a) Nonstimulated cells stained with control immunoglobulin (Ig)-G (solid line, median fluorescence value $(\mathrm{mfv})=0.40)$ or anti-Fas antibody (shaded area, $\mathrm{mfv}=1.30$ ). b) Cells stimulated with interferon (IFN)- $\gamma\left(40 \mathrm{ng} \cdot \mathrm{mL}^{-1}\right)$ for $6 \mathrm{~h}$ were stained with control $\mathrm{IgG}$ (solid line, $\mathrm{mfv}=0.40$ ) or anti-Fas antibody (shaded area, $\mathrm{mfv}=1.51$ ). c) Cells stimulated with tumour necrosis factor (TNF)- $\alpha\left(4 \mathrm{ng} \cdot \mathrm{mL}^{-1}\right)$ for $24 \mathrm{~h}$ were stained with control IgG (solid line, $\mathrm{mfv}=0.40$ ) or anti-Fas antibody (shaded area, $\mathrm{mfv}=1.25)$. d) Cells pretreated with IFN- $\gamma\left(40 \mu \mathrm{g} \cdot \mathrm{mL}^{-1}\right)$ for $6 \mathrm{~h}$ and stimulated by TNF- $\alpha\left(4 \mathrm{ng} \cdot \mathrm{mL}^{-1}\right)$ for $24 \mathrm{~h}$ were stained with control IgG (solid line, $\mathrm{mfv}=0.41$ ) or anti-Fas antibody (shaded area, $\mathrm{mfv}=2.90$ ). The data are representative of three different experiments.

\section{Results}

\section{Expression of Fas antigen}

Figure 1 shows the results of flow cytometry for the Fas expression in WI-38 cells. Fas was expressed constitutively in WI-38 cells. Fas expression on WI-38 cells was slightly upregulated $24 \mathrm{~h}$ after incubation with $4 \mathrm{ng} \cdot \mathrm{mL}^{-1} \mathrm{TNF}-\alpha$ and pretreatment with $40 \mathrm{ng} \cdot \mathrm{mL}^{-1}$ IFN- $\gamma$, but not after incubation with IFN- $\gamma$ or TNF- $\alpha$ alone.

\section{Resistance to Fas-mediated apoptosis}

Apoptosis of WI-38 cells was monitored for early cellular effects by staining with phycoerythrin-labelled Apo2.7 antibody, and also for DNA fragmentation by staining with PI. The results of flow cytometric analysis showed that either administration of $4 \mathrm{ng} \cdot \mathrm{mL}^{-1} \mathrm{TNF}$ $\alpha, 100 \mathrm{ng} \cdot \mathrm{mL}^{-1} \mathrm{CH}-11$, or $\mathrm{CH}-11$ pretreated with $40 \mathrm{ng} \cdot \mathrm{mL}^{-1}$ IFN- $\gamma$ did not induce apoptosis at $24 \mathrm{~h}$, as assessed by Apo2.7 and PI on WI-38 cells (fig. 2). In addition, increased Fas expression after the administration of TNF- $\alpha$ with pretreatment of IFN $-\gamma$ did not effect the susceptibility to $\mathrm{CH}-11$. The effect of higher $\mathrm{CH}-11$ concentrations (500 and $1000 \mathrm{ng} \cdot \mathrm{mL}^{-1}$ ) was also examined. These concentrations did not
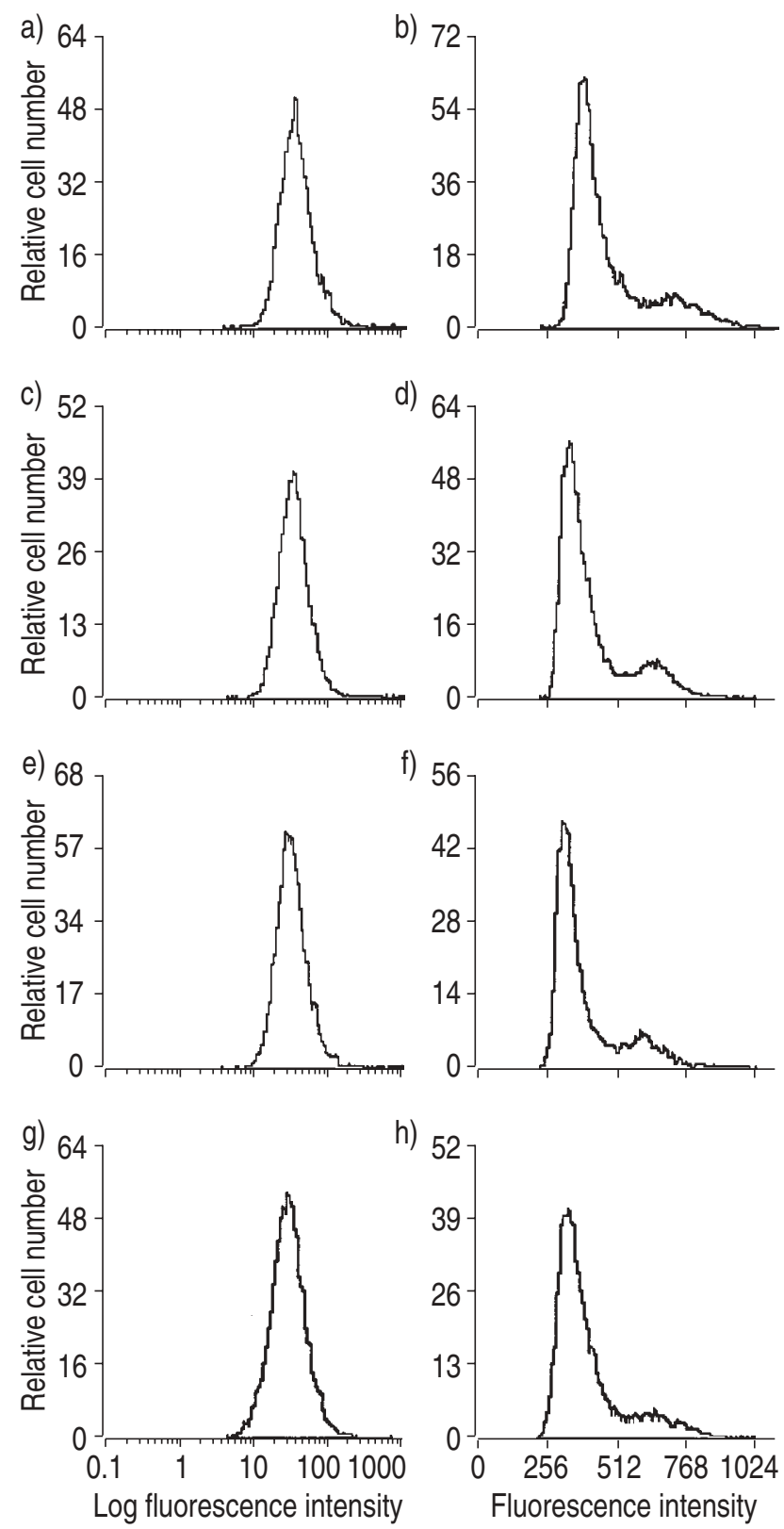

Fig. 2.-WI-38 cells were monitored for early apoptotic effect staining with phycoerythrin-labelled Apo2.7 antibody (a, c, e and $\mathrm{g}$ ), and also for deoxyribonucleic acid fragmentation by staining with propidium iodide (PI) (b, d, f and h). a) and b) Nonstimulated cells. c) and d) Cells stimulated with tumour necrosis factor$\alpha\left(4 \mathrm{ng} \cdot \mathrm{mL}^{-1}\right)$ for $24 \mathrm{~h}$. e) and f) Cells stimulated with CH-11 $\left(100 \mathrm{ng} \cdot \mathrm{mL}^{-1}\right)$ for $24 \mathrm{~h}$. g) and h) Cells pretreated with interferon- $\gamma$ $\left(40 \mathrm{ng} \cdot \mathrm{mL}^{-1}\right)$ for $6 \mathrm{~h}$ and stimulated with $\left(100 \mathrm{ng} \cdot \mathrm{mL}^{-1}\right)$ for $24 \mathrm{~h}$. The data are representative of three different experiments.

change the cell morphology or number of apoptotic cells detected by flow cytometry compared with controls, even at $48 \mathrm{~h}$ after treatment.

The effect of tumour necrosis factor- $\alpha$ or agonistic antiFas antibody (CH-11) on the proliferation and cell cycle

Figure 3 shows the proliferation and cell cycle of WI-38 cells cultured with TNF- $\alpha$ or $\mathrm{CH}-11$, assessed by MTT assay and flow cytometry. Neither TNF- $\alpha$ 

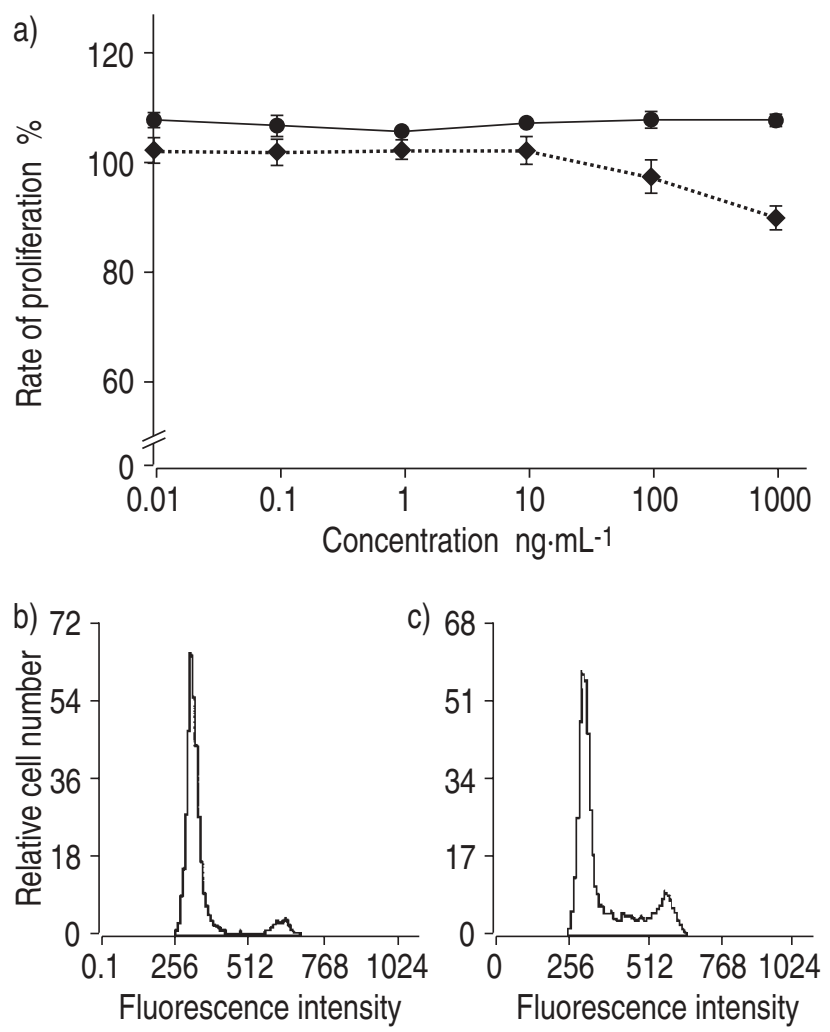

Fig. 3. - The effect of Fas ligation on the proliferation and cell cycle of WI-38 cells. a) Proliferation of WI-38 cells cultured with CH-11 (....) or tumour necrosis factor (TNF)- $\alpha(-)$ assessed by the MTT (3-[4,5-dim ethylthiazol-2-yl]-2,5-diphenyl tetrazolium bromide) assay. Results are shown as the mean of six independent wells \pm SD. b) and c) Cell cycle determined by flow cytometry using propidium iodide (PI). Cells were stimulated with $\mathrm{CH}-11$ (b: $1 \mu \mathrm{g} \cdot \mathrm{mL}^{-1}$ ) or TNF- $\alpha\left(\mathrm{c}: 1 \mu \mathrm{g} \cdot \mathrm{mL}^{-1}\right)$ for $48 \mathrm{~h}$. The data are representative of three different experiments.

nor CH-11 affected the proliferation of WI-38 cells (fig. $3 \mathrm{a}$ ), while a high concentration of $\mathrm{TNF}-\alpha$ $\left(1 \mu \mathrm{g} \cdot \mathrm{mL}^{-1}\right)$ increased the number of cells in $\mathrm{S}$ phase, as measured by flow cytometry using PI staining (fig. 3b). Although it appears that $1,000 \mathrm{ng} \cdot \mathrm{mL}^{-1}$ of $\mathrm{CH}-11$ resulted in a $10 \%$ decrease in the rate of cell proliferation, this change was not statistically significant.

\section{Induction of apoptosis}

The results of flow cytometry using Apo.2.7 and PI staining demonstrated that the administration of cycloheximide concurrently with $100 \mathrm{ng} \cdot \mathrm{mL}^{-1} \mathrm{CH}-11$, but not either $\mathrm{CH}-11$ or cycloheximide alone, induced apoptosis in $57.7 \pm 12.1 \%$ of WI-38 cells after $24 \mathrm{~h}$ (fig. 4). Electron microscopic findings showed that WI-38 cells treated with CH-11 and cycloheximide for $48 \mathrm{~h}$ developed the appearance of "dark cells", condensed chromatin, and cell shrinkage, which are characteristic features of apoptotic cells (fig. 5).

\section{Activation of caspases}

Figure 6 shows Western blot analysis of procaspase$3,-8$, and -9 on cell lysate of WI-38 cells. Procaspase- 3 and -8 but not procaspase- 9 were cleaved $48 \mathrm{~h}$
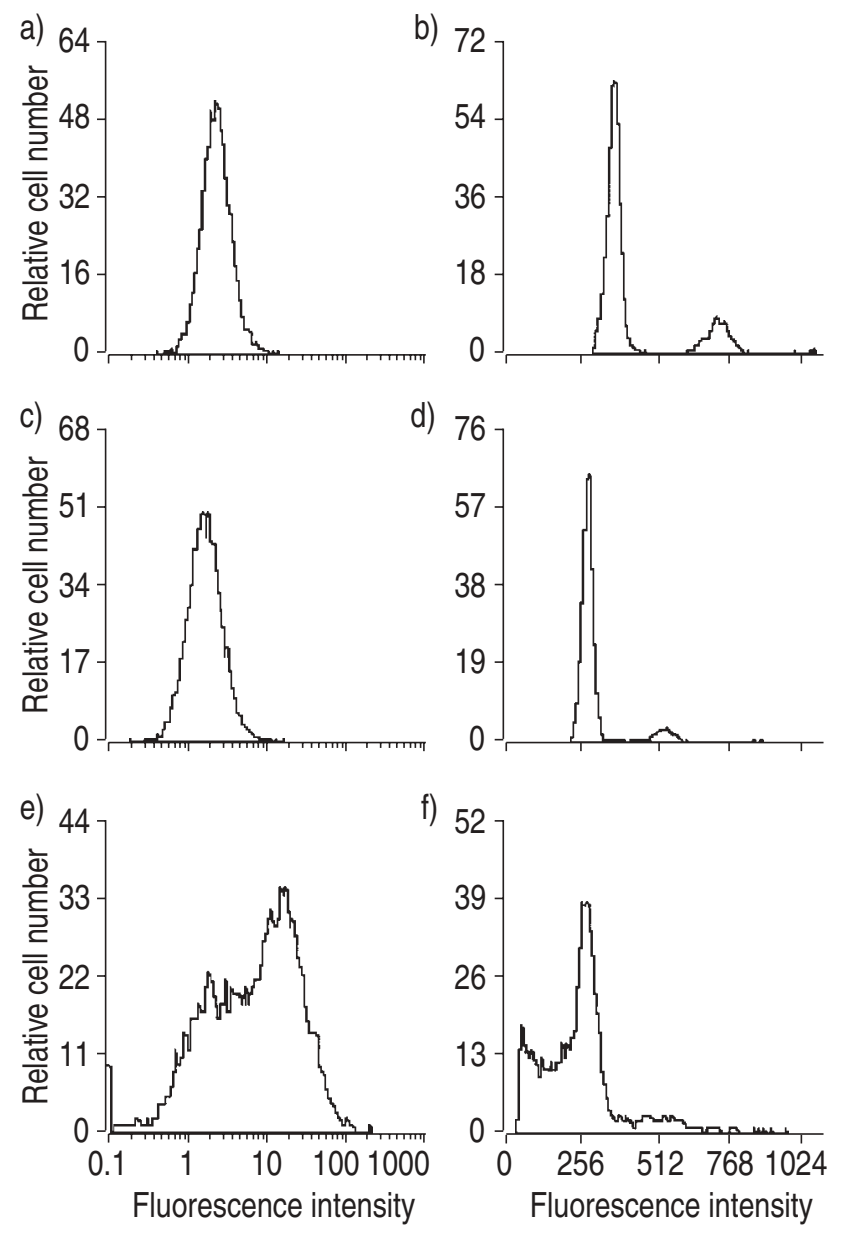

Fig. 4.-Apoptosis of WI-38 cells induced by $\mathrm{CH}-11$ with cycloheximide stained with phycoerythrin-labelled Apo2.7 (a, c and e) or propidium iodide (PI) (b, d and f). a) and b) Cells stimulated with CH-11 (100 ng. $\left.\mathrm{mL}^{-1}\right)$ for $24 \mathrm{~h}$. c) and d) Cells stimulated with cycloheximide $\left(100 \mu \mathrm{g} \cdot \mathrm{mL}^{-1}\right)$ for $24 \mathrm{~h}$. e) and f) Cells stimulated with $\mathrm{CH}-11 \quad\left(100 \mathrm{ng} \cdot \mathrm{mL}^{-1}\right)$ and cycloheximide $\left(100 \mu \mathrm{g} \cdot \mathrm{mL}^{-1}\right)$ for $24 \mathrm{~h}$. Fifty-seven and $33 \%$ of WI-38 cells were positively stained for Apo 2.7 and PI, respectively. The data are representative of three different experiments.

after treatment with $100 \mathrm{ng} \cdot \mathrm{mL}^{-1} \mathrm{CH}-11$ with cycloheximide, while these proteins were not cleaved on untreated cells or on cells treated with either cycloheximide or $\mathrm{CH}-11$ alone.

\section{Expression of anti-apoptotic proteins}

Figure 7 shows protein levels of bcl-2, bcl- $x_{\mathrm{L}}$, FLIP $_{\mathrm{L}}$, and ILP on WI-38 cells. The incubation with $100 \mathrm{ng} \cdot \mathrm{mL}^{-1} \mathrm{CH}-11$ alone did not effect the expression of these proteins, whereas cycloheximide alone decreased the expression of ILP and $b c l-x_{L}$, but not bcl-2 and FLIP as compared with untreated cells. At $24 \mathrm{~h}$ after the co-administration of $\mathrm{CH}-11$ with cycloheximide, the expression of ILP and FLIP $\mathrm{L}_{\mathrm{L}}$ were markedly decreased compared with untreated cells.

\section{Apoptosis in primary human lung fibroblasts}

Figure 8 shows the results of flow cytometry using Annexin-V FITC staining. The administration of 

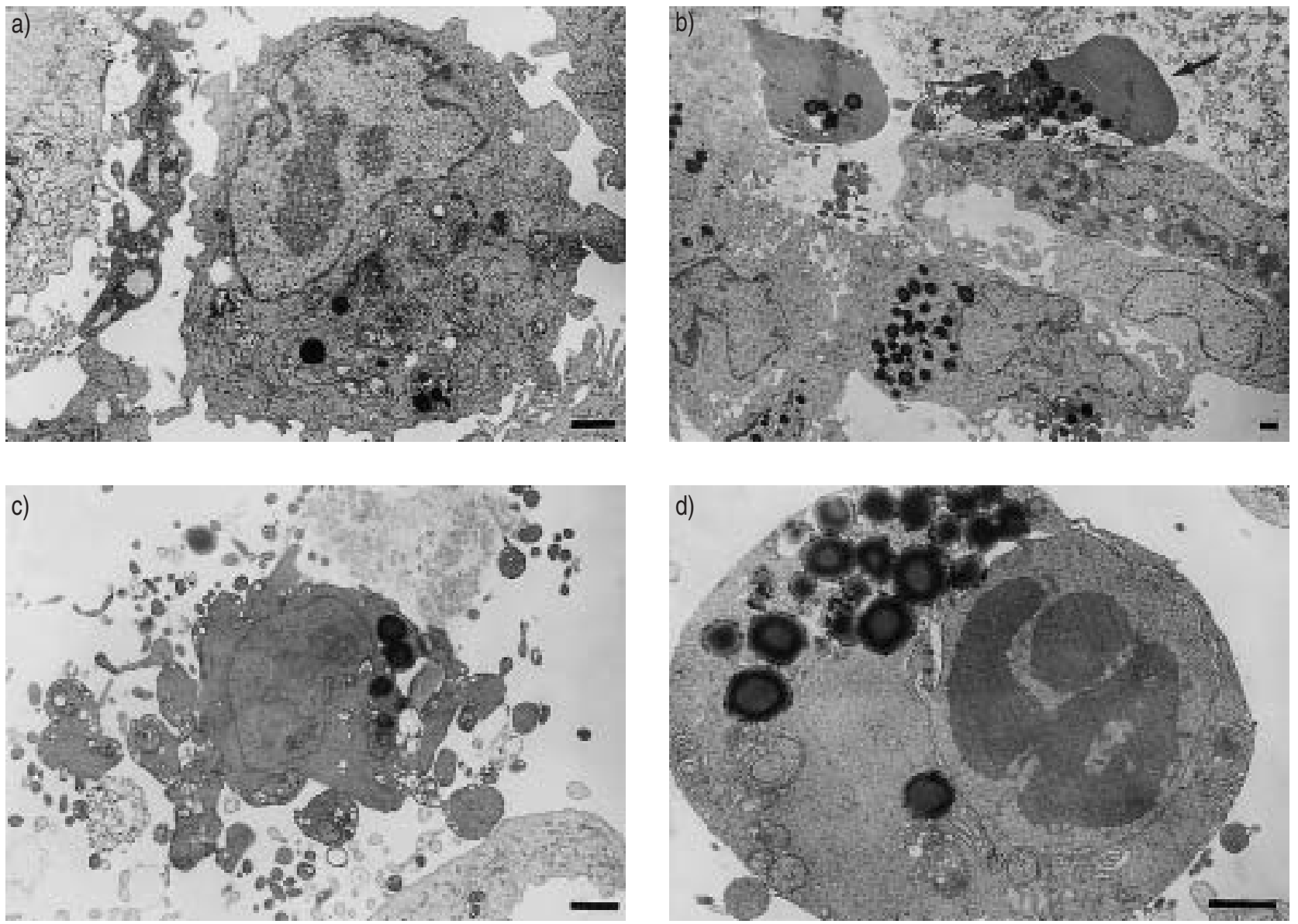

Fig. 5. - Electron microscopic findings on WI-38 cells. a) Untreated cells. WI-38 cells treated with $\mathrm{CH}^{-11}\left(100 \mathrm{ng} \cdot \mathrm{mL}^{-1}\right)$ and cycloheximide $\left(100 \mu \mathrm{g} \cdot \mathrm{mL}^{-1}\right)$ for $48 \mathrm{~h}$ showed b) "dark cells" (arrow), c) cell shrinkage and blebbing, and d) condensed chromatin and disappearance of processes on the cell membrane. (Scale bar=1 $\mu \mathrm{m}$ ).

cycloheximide concurrently with $100 \mathrm{ng} \cdot \mathrm{mL}^{-1} \mathrm{CH}-11$ induced apoptosis on $23.5 \pm 4.5 \%$ of primary human lung fibroblasts after $24 \mathrm{~h}$, whereas $\mathrm{CH}-11$ alone had no effect. A higher concentration of $\mathrm{CH}-11$ (500 and $1000 \mathrm{ng} \cdot \mathrm{mL}^{-1}$ ) did not change the shape of cells or the percentage of apoptotic cells detected by flow cytometry, as compared with controls. In contrast to WI-38 cells, the administration of cycloheximide alone induced apoptosis in $8.3 \pm 3.3 \%$ of these cells after $24 \mathrm{~h}$.

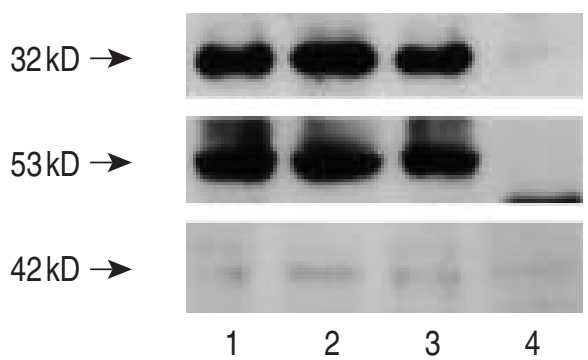

Procaspase-3

Procaspase-8

Procaspase-9

Fig. 6.-Western analysis of procaspases in WI-38 cells. The precursor form of procaspase-3, -8, and -9 in cell lysates of untreated cells (lane 1), cells at $48 \mathrm{~h}$ after cycloheximide alone (lane 2), CH-11 alone (lane 3), or $\mathrm{CH}-11$ with cycloheximide administration (lane 4). The data are representative of three different experiments.
Figure 9 shows protein levels of bcl-2, bcl- $x_{L}$, FLIP $_{L}$, and ILP in primary human lung fibroblasts. The incubation with $\mathrm{CH}-11$ alone increased the expression of ILP and FLIP as compared with

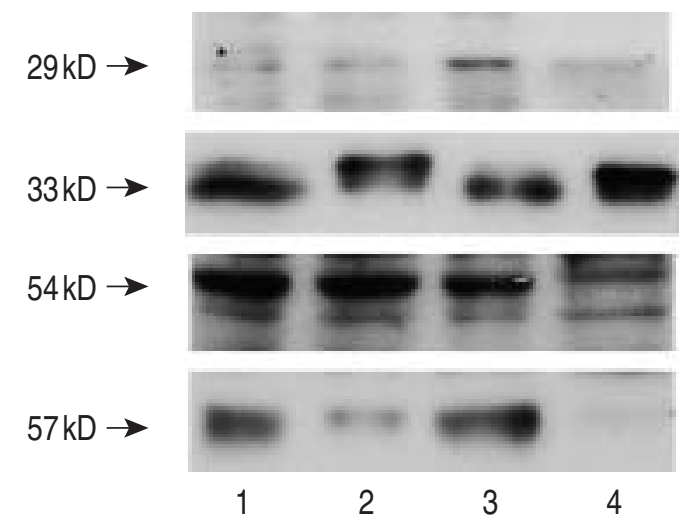

bcl-2

$\mathrm{bcl-X} \mathrm{L}$

FLIPL

Fig. 7.-Western analysis of anti-apoptotic proteins in WI-38 cells. Protein levels of bcl-2, bcl- $x_{L}$, FLICE-like inhibitor protein $\left(\right.$ FLIP $\left._{\mathrm{L}}\right)$, and $\mathrm{X}$ chromosome-linked inhibitor of apoptosis (ILP) in cell lysates of untreated cells (lane 1), cells at $48 \mathrm{~h}$ after cycloheximide alone (lane 2), $\mathrm{CH}-11$ alone (lane 3), or $\mathrm{CH}-11$ with cycloheximide administration (lane 4). The data are representative of three different experiments. 

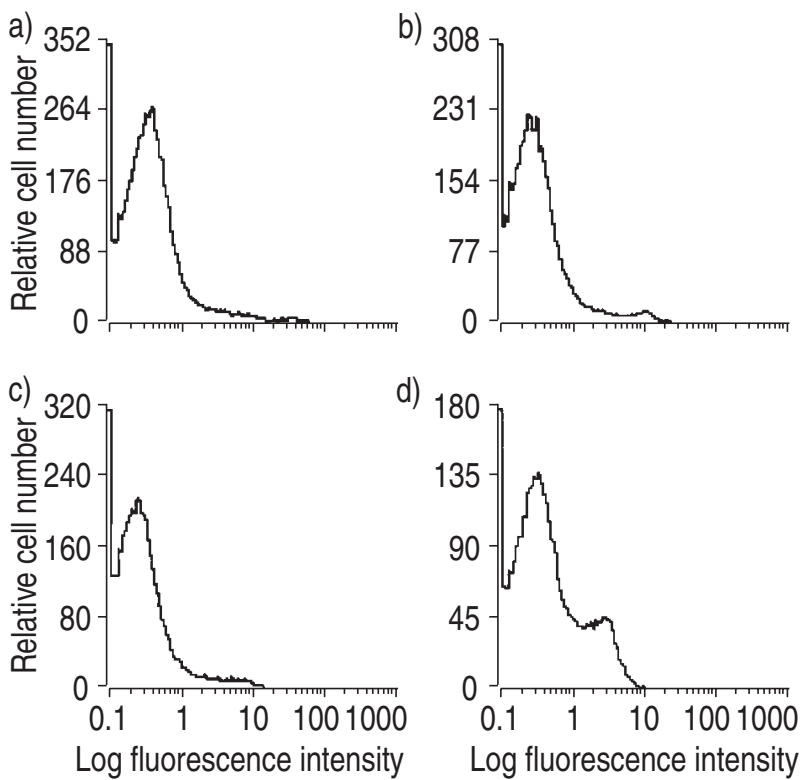

Fig. 8. - Apoptosis of primary lung fibroblasts induced by $\mathrm{CH}-11$ and cycloheximide, stained with Annexin-V fluorescein isothiocyanate. a) Untreated cells, b) cells stimulated with cycloheximide $\left(100 \mu \mathrm{g} \cdot \mathrm{mL}^{-1}\right)$ for $24 \mathrm{~h}, \quad$ c) cells stimulated with $\mathrm{CH}-11$ $\left(100 \mathrm{ng} \cdot \mathrm{mL}^{-1}\right)$ for $24 \mathrm{~h}$, and d) cells stimulated with $\mathrm{CH}-11$ $\left(100 \mathrm{ng} \cdot \mathrm{mL}^{-1}\right)$ with cycloheximide $\left(100 \mu \mathrm{g} \cdot \mathrm{mL}^{-1}\right)$ for $24 \mathrm{~h}$. The data are representative of three different experiments.

untreated cells. The incubation with cycloheximide alone decreased the expression of ILP and FLIP $_{L}$, as compared with untreated cells. Co-administration of CH-11 with cycloheximide decreased ILP expression compared with untreated cells, and decreased FLIP $_{\mathrm{L}}$ and ILP compared with cells treated with $\mathrm{CH}-11$ alone.

\section{Immunohistochemistry for X chromosome-linked inhibitor of apoptosis and FLICE-like inhibitor protein}

Figure 10 shows the representative results of immunohistochemistry for ILP and FLIP $_{\mathrm{L}}$. Prominent signals for ILP and FLIP $_{L}$ were detected in fibroblasts as well as bronchiolar and alveolar epithelial cells in all cases of IPF. Positive signals for these molecules were detected in a few bronchiolar epithelial cells and macrophages in lung tissues from normal lung parenchyma. There was no positive signal in control sections incubated with nonimmune goat serum instead of specific antibodies.

\section{Discussion}

The WI-38 cell is a human diploid lung fibroblast cell line. This cell line was used because the purpose of this study was to investigate how lung fibroblasts respond to Fas ligation in fibrosing lung tissues, in which the Fas-Fas ligand pathway may be involved in the pathogenesis. WI-38 cells were resistant to Fas ligation using a high concentration of $\mathrm{CH}-11$. When CH-11 was administered with cycloheximide, WI-38

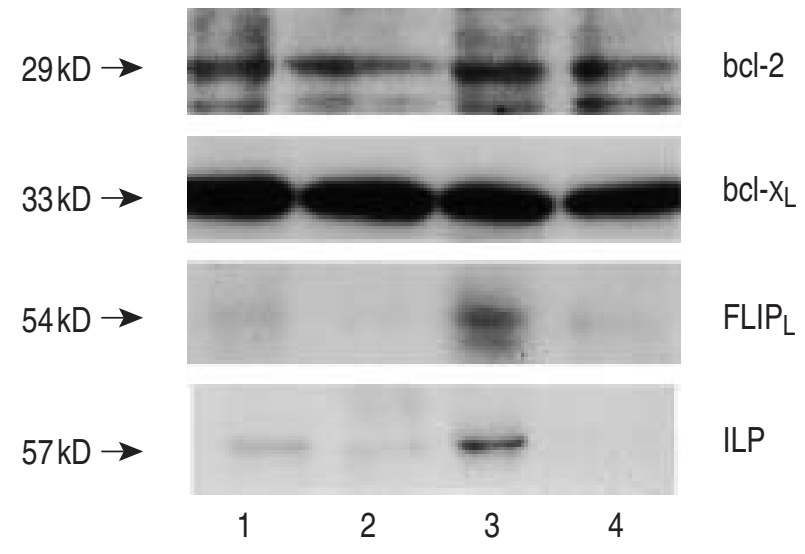

Fig. 9.-Western analysis of anti-apoptotic proteins in primary lung fibroblasts. Protein levels of bcl-2, bcl- $x_{L}$, FLICE-like inhibitor protein $\left(\mathrm{FLIP}_{\mathrm{L}}\right)$ and $\mathrm{X}$ chromosome-linked inhibitor of apoptosis (ILP) in cell lysates of untreated cells (lane 1), cells at $48 \mathrm{~h}$ after cycloheximide alone (lane 2), $\mathrm{CH}-11$ alone (lane 3), or $\mathrm{CH}-11$ with cycloheximide (lane 4). Data is representative of three different experiments.

cells were induced to undergo apoptosis, as assessed by flow cytometry and electron microscopy. Therefore, these results suggest that the expression of antiapoptotic proteins may be associated with resistance to Fas-mediated apoptosis on WI-38 cells. WI-38 cells constitutively express bcl-2, bcl- $\mathrm{x}_{\mathrm{L}}, \mathrm{FLIP}_{\mathrm{L}}$, and ILP. Co-administration of CH-11 with cycloheximide induced apoptosis in WI-38 cells, and markedly

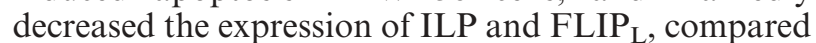
with untreated cells.

To verify how WI-38 cells differ from primary lung fibroblasts, experiments were performed using primary human lung fibroblasts. Primary lung fibroblasts were also resistant to Fas ligation even at a high $\mathrm{CH}$ 11 concentration $\left(1 \mu \mathrm{g} \cdot \mathrm{mL}^{-1}\right)$, and were susceptible only in the presence of cycloheximide, like WI-38 cells. In WI-38 cells, FLIP F $_{\text {ILP }}$ ande decreased after co-administration of $\mathrm{CH}-11$ with cycloheximide, and ILP were decreased after the administration of cycloheximide alone as compared with untreated cells. In primary lung fibroblasts, FLIP $_{\mathrm{L}}$ and ILP were also decreased by the co-administration of $\mathrm{CH}-11$ with cycloheximide compared with treatment with $\mathrm{CH}-11$ alone. Furthermore, FLIP L $_{\text {and ILP were decreased }}$ after the administration of cycloheximide, when compared with untreated cells. Although WI-38 cells and primary lung fibroblasts were cultured in different media, it is unlikely that fibroblast growth factor increased the susceptibility of primary fibroblasts to $\mathrm{CH}-11$-induced apoptosis. These results suggest that anti-apoptotic proteins ILP and FLIP $_{\mathrm{L}}$ may participate in the resistance of lung fibroblasts to Fas-mediated apoptosis.

Different clones of fibroblasts differ in their responses to Fas ligation. JELASKA et al. [24] demonstrated that human adult skin dermal fibroblasts were more susceptible to Fas ligation than foreskin fibroblasts, in which Fas ligation induced proliferation rather than apoptosis. AgGarwal et al. [25] also demonstrated that Fas ligation signals proliferation of these cells. In contrast to dermal fibroblasts, in 

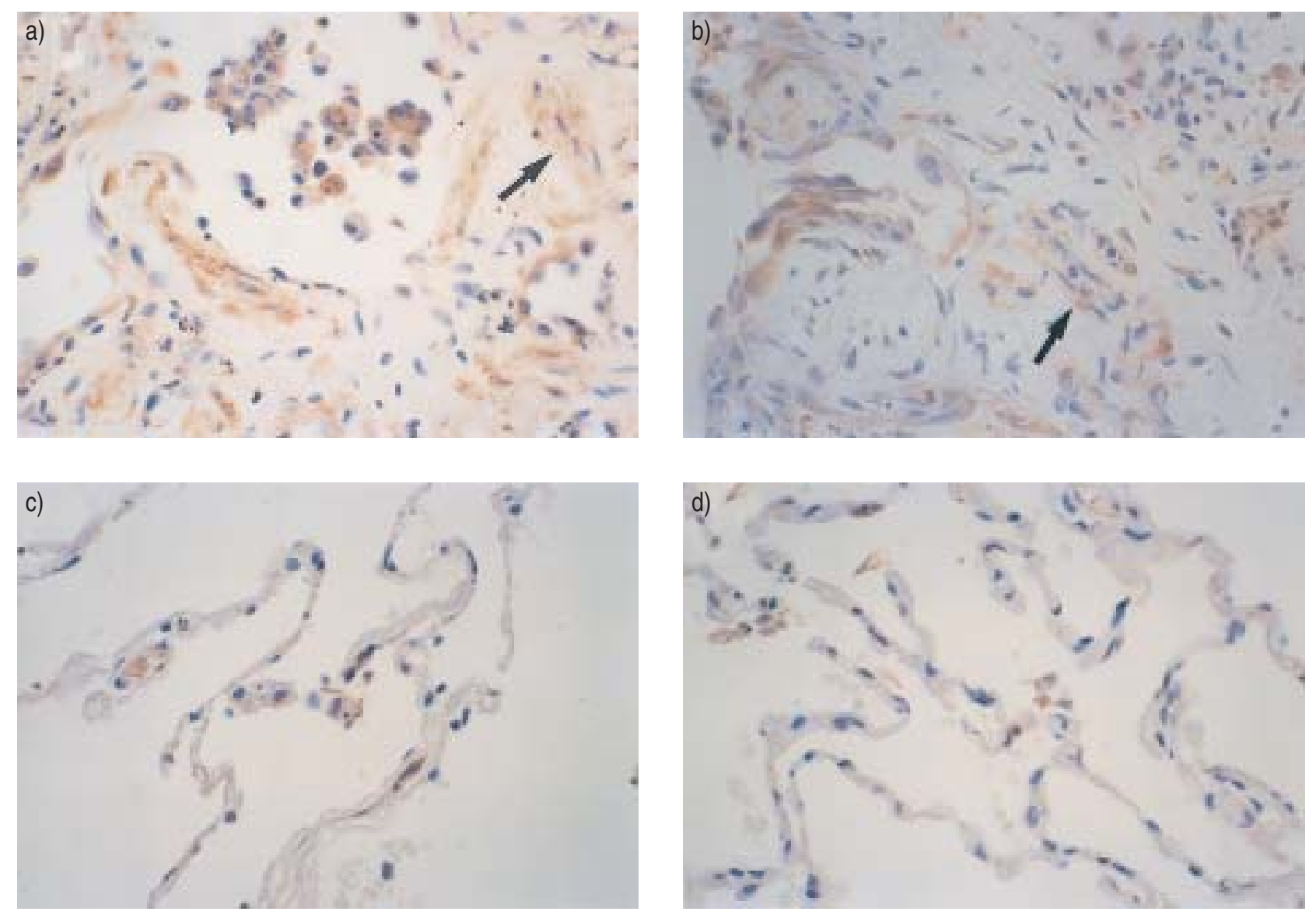

Fig. 10.-Immunohistochemistry for $\mathrm{X}$ chromosome-linked inhibitor of apoptosis (ILP) and FLICE-like inhibitor protein (FLIP $\mathrm{L}_{\mathrm{L}}$. Prominent signals for a) ILP and b) FLIP $_{\mathrm{L}}$ were detected in fibroblasts (arrows) as well as bronchiolar and alveolar epithelial cells in lung tissue from patients with idiopathic pulmonary fibrosis. Positive signals for c) ILP and d) FLIP $_{L}$ were detected in a few bronchiolar epithelial cells and macrophages in lung tissues from normal lung parenchyma.

agreement with previously published results of TEPPER et al. [21], it was found that WI-38 were susceptible to Fas-mediated apoptosis only in the presence of cycloheximide. Therefore, lung fibroblasts seem to be more resistant against Fas-ligation than other types of fibroblasts.

Cycloheximide and CH-11 appear to decrease ILP and FLIP expression, not only in comparison to untreated, but also cycloheximide-treated WI-38 cells. This seems unexpected since Fas ligation induces NF- $\kappa \mathrm{B}$ dependent expression of anti-apoptotic proteins. Recently, SAELENCE et al. [26] reported a new and caspase-dependent activation model for double stranded ribonucleic acid-regulated protein kinase (PKR), leading to eukaryotic initiation factor 2 (eIF2- $\alpha$ ) phosphorylation and translation inhibition in apoptosis. It also has been reported that caspase activation cleaves ILP [27], which may accelerate the decrease in ILP expression induced by cycloheximide. These mechanisms may enhance the decrease of ILP and FLIP in apoptotic cells.

Fas antigen was constitutively expressed on fibroblasts as well as lung epithelial cells. However, epithelial cells, but not fibroblasts, were induced to undergo apoptosis by treatment with $\mathrm{CH}-11$ alone [28]. Using immunohistochemistry, Minowa et al. [29] demonstrated that Fas was expressed on many kind of cells, including epithelial cells, fibroblasts, endothelial cells and macrophages in lung tissues from patients with IPF. The present authors previously showed that FasL expression was upregulated, and apoptotic cells were predominantly epithelial cells in lung tissues from patients with IPF [7,8]. These results in vitro and in vivo suggest that intracellular Fas signalling pathway in fibroblasts is different from that in epithelial cells.

ILP can suppress apoptotic death signalling by the formation of an active caspase-3/ILP complex, with subsequent inhibition of caspase-3 activity [16]. Apoptosis usually requires the activation of caspases, and the particular caspases necessary vary according to the cell type and the stimulus which triggers cell death. The ability of each IAP family member to inhibit apoptosis may also vary, depending on cell type and the signalling pathway leading to apoptosis. ILP may only be an effective inhibitor of apoptotic stimuli that depend on caspase-3 and/or caspase-7 [16]. In this study, ILP was expressed in both fibroblasts and epithelial cells in lung tissues from patients with IPF. Recently, the expression of ILP in lung epithelial cell lines has been demonstrated [30]. The present authors also found that mouse lung 
epithelial cells were induced to undergo apoptosis by Fas ligation alone, in these cells ILP protein was decreased. Therefore, there may be a mechanism to prevent ILP protein degradation or proteolysis induced by Fas ligation in fibroblasts.

Death receptor-mediated and mitochondrialmediated pathways represent two principal signalling pathways of apoptosis. Activation of death receptors results in the recruitment of adapter proteins through interaction of death domains. Recruitment of FADD to Fas activates initiator caspase-8 [18]. Stimuli other than death receptor activation, such as anti-cancer drugs, radiation, and reactive oxygen radicals, trigger apoptotic pathways involving mitochondria. Cytochrome $\mathrm{c}$ is released into the cytosol from mitochondria and binds to apoptosis protease activating factor 1 , with adenosine triphosphate, which results in the activation of caspase-9 [31]. In some cells, Fas-ligation induces caspase-9 activation through proteolysis of BID well as caspase-8 [32]. The activation of caspase- 8 or caspase-9 leads to the activation of effector caspases, such as caspase-3. Since caspase- 8 and caspase-3, but not caspase-9, were activated on WI-38 cells by the administration of $\mathrm{CH}-11$ with cycloheximide, it is likely that the apoptotic pathway in WI-38 cells induced by $\mathrm{CH}-11$ with cycloheximide is

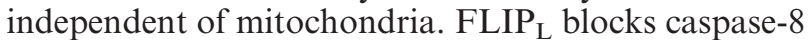
activation [20]. IAPs block caspase-3, caspase 7, and caspase-9 directly, and also inhibit caspase- 8 along with TNF receptor associated factors $[16,33]$. Therefore, the decrease of $\mathrm{FLIP}_{\mathrm{L}}$ and ILP expression induced by $\mathrm{CH}-11$ with cycloheximide treatment may result in caspase activation in WI-38 cells.

The presence of intact epithelial cells controls fibroblast proliferation. Studies on the re-population of denuded tracheal explants by epithelial cells show that the denuded tracheal implants are rapidly replaced by fibroblasts, unless enough epithelial cells are introduced into the lumen to control fibroblast proliferation [34]. The authors conclude that the fibroblast proliferation is a direct result of epithelial cell damage. Uhal et al. [35] demonstrated that fibroblasts isolated during fibrotic lung injury produce a soluble factor capable of inducing apoptosis of alveolar epithelial cells in vitro. They also demonstrated that epithelial cell apoptosis, necrosis, and cell loss were detected adjacent to foci of collagen accumulation surrounding fibroblast-like cells in lung tissues from patients with IPF [36]. Since the abnormal epithelium-fibroblast interaction participates in the pathophysiology of pulmonary fibrosis, the regulation of anti-apoptotic proteins in fibroblasts may be critical in the pathogenesis of IPF.

The present authors conclude that lung fibroblasts are resistant to Fas-mediated apoptosis. This resistance is likely due to the inhibitory effect of anti-apoptotic proteins such as inhibitor of apoptosis and FLICE-like inhibitor protein on intracellular signalling pathway of Fas-mediated apoptosis. Understanding the function of these proteins, which seems to be different depending on cell-type and apoptotic stimuli, may lead to the development of novel therapies for pulmonary fibrosis.

\section{References}

1. Itoh N, Yonehara S, Ishii A, et al. The polypeptide encoded by the cDNA for human cell surface antigen Fas can mediate apoptosis. Cell 1991; 66: 233-243.

2. Suda $T$, Takahashi $T$, Golstein $T$, Nagata $S$. Molecular cloning and expression of Fas ligand, a novel member of the tumor necrosis factor family. Cell 1993; 75: 1169-1178.

3. Hiramatsu N, Hayashi N, Katayama K, et al. Immunohistochemical detection of Fas antigen in liver tissue of patients with chronic hepatitis C. Hepatology 1994; 19: 1354-1359.

4. Sayama K, Yonehara S, Watanabe Y, Miki Y. Expression of Fas antigen on keratinocytes in vivo and induction of apoptosis in cultured keratinocytes. J Invest Dermatol 1994; 103: 330-334.

5. Fine A, Anderson NL, Rothstein TL, Williams MC, Gochuico BR. Fas expression in pulmonary alveolar type II cells. Am J Physiol 1997; 273: L64-L71.

6. Felzen B, Shilklut M, Less H, et al. Fas (CD95/Apo1)-mediated damage to ventricular myocytes induced by cytotoxic $\mathrm{T}$ lymphocytes from perforin-deficient mice: a major role for inositol 1,4,5-triphosphate. Circ Res 1998; 82: 438-450.

7. Kuwano K, Miyazaki H, Hagimoto N, et al. The involvement of Fas-Fas ligand pathway in fibrosing lung diseases. Am J Respir Cell Mol Biol 1999; 20: 5360 .

8. Kuwano K, Kunitake R, Kawasaki M, Nomoto Y, Hagimoto N, Hara N. P21Waf1/Cip1/Sdil and p53 expression in association with DNA strand breaks in idiopathic pulmonary fibrosis. Am J Respir Crit Care Med 1996; 154: 477-483.

9. Hagimoto N, Kuwano K, Nomoto Y, Kunitake R, Hara N. Apoptosis and expression of Fas/Fas ligand pathway in bleomycin-induced pulmonary fibrosis in mice. Am J Respir Cell Mol Biol 1997; 16: 91-101.

10. Hagimoto N, Kuwano K, Miyazaki H, et al. Induction of apoptosis and pulmonary fibrosis in mice in response to ligation of Fas antigen. Am J Respir Cell Mol Biol 1997; 17: 272-278.

11. Reed J. Bcl-2 and the regulation of programmed cell death. J Cell Biol 1994; 124: 1-6.

12. Boise L, Gonzalez-Garcia M, Postema C, et al. Bcl-x, a bcl-2-related gene that functions as a dominant regulator of cell death. Cell 1993; 74: 597-608.

13. Hockenbery D, Oltvai Z, Yin X, Milliman C, Korsmeyer S. Bcl-2 functions in an antioxidant pathway to prevent apoptosis. Cell 1993; 75: 241-251.

14. Itoh N, Tsujimoto $\mathrm{Y}$, Nagata $\mathrm{S}$. Effect of bcl-2 on Fas-mediated cell death. J Immunol 1993; 151: 621627.

15. Thornberry NA, Lazebink Y. Caspases: enemies within. Science 1998; 281: 1312-1316.

16. Deveraux QL, Takahashi R, Salvesen GS, Reed JC. $\mathrm{X}$-linked IAP is a direct inhibitor of cell-death proteases. Nature 1997; 388: 300-303.

17. Suzuki A, Tsutomi Y, Akahane K, Araki T, Miura M. Resistance to Fas-mediated apoptosis: activation of caspase 3 is regulated by cell cycle regulator p21 WAF1 and IAP gene family ILP. Oncogene 1998; 17: 931-939.

18. Yeh WC, de la Pompa JL, McCurrach ME, et al. FADD: essential for embryo development and signaling from some, but not all, inducers of apoptosis. Science 1998; 279: 1954-1958.

19. Thome M, Schneider P, Hofmann K, et al. Viral 
FLICE-inhibitory proteins (FLIPS) prevent apoptosis induced by death receptors. Nature 1997; 386: $517-$ 521.

20. Irmler $\mathbf{M}$, Thorme $\mathbf{M}$, Schneider $\mathrm{P}$, et al. Inhibition of death receptor signals by cellular FLIP. Nature 1997; 388: 190-195.

21. Tepper CG, Seldin MF, Mudryj M. Fas-mediated apoptosis of proliferating, transiently growth arrested, and senescent normal human fibroblasts. Exp Cell Res 2000; 260: 9-19.

22. Mosmann T. Rapid colorimetric assay for cellular growth and survival: application to proliferation and cyctotoxicity assay. J Immunol Methods 1983; 65: 55-63.

23. Zhang C, Ao Z, Zeth A, Schlossman SF. A mitochondrial membrane protein defined by a novel monoclonal antibody is preferentially detected in apoptotic cells. J Immunol 1996; 157: 3980-3987.

24. Jelaska A, Kohn JH. Anti-fas induces apoptosis and proloferation in human dermal fibroblasts: Differences between foreskin and adult fibroblasts. $J$ Cell Physiol 1998; 175: 19-29.

25. Aggarwal BB, Singh S, LaPushin R, Totpal K. Fas antigen signals proliferation of normal human diploid fibroblast and its mechanism is different from tumor necrosis factor receptor. FEBS Lett 1995; 364: 5-8.

26. Saelence X, Kalai M, Vandenabeele P. Translation inhibition in apoptosis. Caspase dependent PKR activation and eIF2-a phosphorylation. $J$ Biol Chem 2001; 276: 41620-41628.

27. Johnson DE, Gastman BR, Wieckowski E, et al. Inhibitor of apoptosis protein hILP undergoes caspase-mediated cleavage during $\mathrm{T}$ lymphocyte apoptosis. Cancer Res 2000; 60: 1818-1823.
28. Hagimoto N, Kuwano K, Kawasaki M, et al. Induction of interleukin-8 secretion and apoptosis in bronchiolar epithelial cells by Fas ligation. Am $J$ Respir Cell Mol Biol 1999; 21: 436-445.

29. Minowa K, Nagai S, Kitaichi M, Izumi T, Oshima A. Expression of bcl-2 protein and APO-1 (Fas antigen) in the lung tissue from patients with idiopathic pulmonary fibrosis. Microsc Res Tech 1997; 38: 480-487.

30. Pryhuber GS, Huyck HL, Staversky RJ, Finkelstein JN, O'Reilly MA. Tumor necrosis factor- $\alpha$-induced lung cell expression of antiapoptotic genes TRAF1 and cIAP2. Am J Respir Cell Mol Biol 2000; 22: 150156.

31. Green DR, Reed JC. Mitochondria and apoptosis. Science 1998; 281: 1309-1312.

32. Li H, Zhu H, Xu C, Yuan J. Cleavage of BID by caspase 8 mediates the mitochondrial damage in the Fas pathway of apoptosis. Cell 1998; 94: 491-501.

33. Deveraux QL, Roy N, Stennicke HR, et al. IAPs block apoptosic events induced by caspase- 8 and cytochrome c by direct inhibition of distinct caspases. EMBO J 1998; 17: 2215-2223.

34. Terzaghi M, Nettesheim P, Williams ML. Re-population of denuded tracheal grafts with normal, pre-neoplastic and neoplastic epithelial cell populations. Cancer Res 1978; 38: 4546-4553.

35. Uhal BD, Joshi 1, True AL, et al. Fibroblasts isolated after fibrotic lung injury induce apoptosis of alveoalr epithelial cells in vitro. Am J Physiol 1995; 269: L819825 .

36. Uhal BD, Joshi 1, Hughes WF, Ramos C, Pardo A, Selman M. Alveolar epithelial cell death adjacent to underlying myofibroblasts in advanced fibrotic human lung. Am J Physiol 1998; 275: L1192-L1199. 